\title{
The Rise of the Third Rome: Russkii Mir and the Rebirth of Christendom
}

\section{David K. Goodin, Université Laval}

\begin{abstract}
This essay brings Douglas John Hall's engagement with the theology of the cross for a postChristendom context into dialogue with the political theology of Russkii mir by the Russian Orthodox Church (ROC). Russkii mir is a theology that claims to be Christendom reborn. It signals a new alliance between the ROC and the Russian Federation by sanctioning military conquest of foreign lands, including Crimea and the ongoing conflict in eastern Ukraine. This essay documents the emergence of this new political theology in terms of its historical precedents and how this history is being distorted, and even invented, to justify the claims to Christendom. Particular attention is given to the architecture and militaristic symbolism for the newly christened Cathedral for the Russian Armed Forces, dedicated on June 14th, 2020. Finally, these claims are critically examined using Hall's theology of the cross as a disestablishment for all such "theologies of glory" in light of scripture, tradition, and the true mission of the church. I also bring Hall's work into dialogue with similar thought from the Orthodox East.
\end{abstract}

Keywords: Russian Orthodox Church, Russkii Mir, Third Rome, Christendom, Byzantium, Warrior Saints

A religious community that believes itself to be in possession of 'the Truth' is a community equipped with the most lethal weapon of any warfare: the sense of its own superiority and mandate to mastery.

- Douglas John Hall, The Cross in Our Context ${ }^{1}$

T The Church of the Holy Resurrection is the Russian Orthodox cathedral for the Russian Federation Armed Forces. It is located thirty-four miles west of Moscow in a complex called Patriot Park. Each of its four chapels is dedicated to a patron saint for each branch of the armed forces airborne/aerospace, strategic missile, navy, and the army. It was dedicated on June 14th, 2020, commemorating the seventy-fifth anniversary of the end of World War II, which is known in Russia as the Great Patriotic War. The dedication served as an auspicious political event, celebrating the resurgence of Russia as a global superpower after the fall of the Soviet Union. It was also an occasion to announce the union of church and state with a single goal in mind, Russkii mir. It is a phrase challenging to translate; it simultaneously denotes "Russian world" and "Russian peace," yet also carries the connotation of exclusivity - that it dominates so that peace then results. The phrase is being used to signal the rebirth of

1. I was fortunate enough to have taken Dr. Hall's final seminar at McGill University before his emeritus status. The course was on the Theology of the Cross. It was a most remarkable experience for all who were present, and most especially for me in terms of my dissertation research. I wish to dedicate this article to Dr. Hall for all he has contributed to my own scholarship. I also wish to extend my gratitude to the anonymous reviewer of this essay, whose insightful suggestions truly proved most helpful. 
Christendom itself, the inauguration of a new Christian empire protected through both religious faith and military might.

The Russkii mir doctrine was announced by both the head of the Russian Orthodox Church (hereinafter ROC), Patriarch Kirill of Moscow and all Rus' (Vladimir Mikhailovich Gundyayev), and the President of the Russian Federation, Vladimir Putin. It is a political theology by which the ROC now lays claim to the "spiritual space" of what are thought of as traditionally Russian lands, that they collectively constitute "one people" under its ecclesial jurisdiction. This includes Russian-speaking regions outside the Russian Federation itself, a doctrine which took on real world consequences with the Russian invasion and annexation of Crimea in 2014. This military action was not only blessed by the ROC, but reportedly facilitated by it. ${ }^{2}$ In turn, Russian president Vladimir Putin has used this same doctrine ${ }^{3}$ as justification for the ongoing conflict with Ukraine, which has seen several predominately Russian-speaking regions in eastern Ukraine undergoing pro-Russian armed insurrection since the Crimean annexation. While there is now an uneasy ceasefire agreement between Ukraine and Russia, the potential for further conflict and annexation is ever-present, perhaps even an inevitability. This is because Putin has recently taken the extraordinarily provocative step of issuing Russian Federation passports to Russian-speaking persons in occupied eastern Ukraine to consolidate control and further his claims to these territories - reportedly, Putin has similar expansionist intentions in mind for the nation of Belarus. ${ }^{4}$

What explains this apparent collusion between the ROC and the Russian Federation? My essay examines the theological origins and political ramifications of Russkii mir with this question in mind, particularly the claims of a new Christendom, understood here as Christian empire. To this end, the historical origins of the Third Rome narrative will be examined, with special attention given to the new ROC Cathedral. Also examined is the emergence of certain false narratives concerning a supposedly Christian context for Soviet resistance during World War II, and how this is reflected in the uncharacteristic architecture and militaristic symbolism of this Cathedral. Next, the subject of "warrior saints" must be approached, and how a sharp demarcation between the Byzantine and Russian traditions helps explain the contemporary fascination of the ROC with a cult of war. My essay will then move to examine these claims to Christendom in light of Douglas John Hall's engagement with the Lutheranism's Theology of the Cross for a post-Christendom context. This will allow for a comparative analysis that, in turn, will become the basis for considering similar decolonializing thought from the Orthodox East.

I begin with the foundational claim that Moscow somehow represents a "Third Rome," by which is meant that it is the last and final seat of heavenly power in the world. Through this doctrine, the ROC is representing itself as the prophetic New Jerusalem in the Christian apocalyptic imagination, an anticipation of the Kingdom of Heaven itself. Considerable space in this essay will be devoted to this subject because of its unfamiliarity for many western readers. This will also be an opportunity to document an emergent

2. See the investigative reporting of Liliya Yapparova in "Holy Men: How Russian Orthodox Priests Helped Annex Crimea," Meduza, April 6, 2020, https://meduza.io/en/feature/2020/04/06/russia-sholy-men.

3. See "Mission Statement," Russkiy Mir Foundation, https://russkiymir.ru/en/fund/. Officially, the foundation - which, established in 2007, is the public face for this initiative - only promotes culture and heritage: "Russkiy Mir reconnects the Russian diaspora with its homeland through cultural and social programs, exchanges and assistance in relocation. The Russian world also includes the millions of people worldwide who have chosen the Russian language as their subject of study, those who have developed an appreciation for Russia and its rich cultural heritage." It should be noted that Metropolitan Hilarion of Volokolamsk is on the Board for Trustees for this Foundation.

4. See the investigative reporting of Taras Kuzio in "Putin Forever: Ukraine Faces the Prospect of Endless Imperial Aggression," Atlantic Council, February 13, 2020, https://www.atlanticcouncil.org/blogs/ukrainealert/putin-foreverukraine-faces-the-prospect-of-endless-imperial-aggression/. 
political phenomenon that has thus far received very little scholarly attention - that is, the Russkii mir political theology.

\section{The Third Rome}

The claim that Moscow is the Third Rome can be traced to the conquest of Constantinople by Ottoman forces in 1453, and the failure of the Council of Florence (1431-1449) which saw the Russian Church declaring its autocephaly. Previously, Constantinople had the honor of being known as the Second Rome, a place of honor as the new Holy City established by the First Council of Constantinople (381 CE). The edict was a pragmatic one. It was necessary for the emperor to relocate the capital to the geographical center of Christian lands. Thus, the ancient city of Byzantium became rechristened as Constantinople, the New Rome. Then, in the wake of the Great Schism of 1054, Constantinople achieved both political and theological primacy in the Orthodox East, the former Rome being seen as lost to heresy in a schism that continues to the present day.

There was a perceived necessity to have a Christian city as the heart of Christendom, not only for the sake of empire, but also to substantiate apocalyptic theology concerning a New Jerusalem for the Kingdom of Heaven (Revelation 3:12 and 21:2). This became greatly complicated when Constantinople fell to invaders, not once but twice - first by Christian crusaders from the west in 1204, and then to the Ottoman invaders from the east in 1453. It left an ecclesial, political, and theological absence at the heart of Orthodox Christianity, at least temporarily. In time, the remnant Constantinople (effectively one administrative district in Istanbul, granted by permission by the Ottomans) reasserted itself in ecclesial matters. But never again would it be a political reality for the dreams of Christian empire. Into this power vacuum, the newly autocephalous ROC rose to counter the theological authority of Catholic Rome. This was announced in 1492 by Metropolitan Zosimus, who declared: "The Emperor Constantine built a New Rome, Tsarigrad; but the sovereign and autocrat (samoderzhets) of All the Russias, Ivan Vasilyevich, the new Constantine, has laid the foundation for a new city of Constantine, Moscow."

This aspiration for Russia was later promoted by Filofei of Pskov (d. 1542), a monk of the Yelizarov Monastery, who around 1515 wrote to Grand Duke Vasily III of Moscow (1479-1533), calling upon him to claim the high office of tsar as representing the third and final Rome:

\footnotetext{
Henceforth we can expect only one kingdom to come. That kingdom is eternal. I have written this because, admiring you as I do, I have appealed and have prayed to God that He may bless you. Change your stinginess to generosity and your inclemency to kindness. Comfort those who cry and moan day and night. Protect the innocent from their tormentors. I repeat here what I have written above. Pious Tsar! Listen and remember that all Christian kingdoms have now merged into one, your [tsardom]. Two Romes have fallen. The third stands [firm]. And there will not be a fourth. No one will replace your Christian tsardom. ${ }^{6}$
}

This prophecy of a New Rome came complete with tsars likened unto emperors in the tradition of the first holy roman emperor, Constantine. Even so, this claim was not recognized in the Orthodox world, not even fully in Russia itself - the failure being underscored in the middle of the seventeenth century in a ROC schism with the Old Ritualists, who appealed to the Ecumenical Patriarch of Constantinople for their cause. The tsarist claim to primacy was also refuted through the deposing of Patriarch Nikon of Moscow (1605-

5. Steven Runciman, The Great Church in Captivity (Cambridge: Cambridge University Press, 1968), 323.

6. Basil Dmytryshyn, Medieval Russia: A Source Book, 850-1700 (Fort Worth, TX: Harcourt Brace Jovanovich, 1991 ), 261. 
1681) in a synod led by non-Russians, including Patriarch Païsius of Alexandria, Patriarch Macarios of Antioch, Ananias of Sinai (representing the Patriarch of Jerusalem), and Metropolitan of Iconium Athanasius representing the Ecumenical Patriarch of Constantinople. To put it simply, the belief that the Patriarchate of Moscow somehow represented a new seat of Christendom was never a historical reality. Rather, it is no more than a "historical ghost" in revisionist popular imagination. ${ }^{7}$

The hope for a Third Rome was further complicated by the Bolshevik Revolution of 1917 when the royal family was murdered by the new atheist government, which then persecuted the ROC in a campaign of brutal oppression - what is referred to today as the Red Terror. Thousands of clergy, monastics, and the faithful were murdered at the direction of Lenin. ${ }^{8}$ Only a historical happenstance halted this terror campaign in 1941 when the Soviets annexed new lands through a temporary alliance with Nazi Germany. The lands were largely Christian, and a temporary suspension of religious persecution was enacted to help consolidate Soviet control. With the outbreak of war with Germany, this pragmatism took on a new public face, one that was “motivated by Stalin's realization of the need for the Church to arouse a sense of patriotic sacrifice in the nation." 9 This led to a remarkable development late in the war. In September 1944, Stalin called for a meeting with three senior hierarchs of the ROC, and in exchange for pledges of loyalty to the state, they were allowed to appoint a state-approved patriarch and reopen their churches. ${ }^{10}$ This new relationship of cooperation, however, required public pronouncements that the earlier campaigns of terror were not state-sponsored activities, but only the actions of "roaming partisan forces." 11 It was a most distressing choice. The clergy were required to lie in order to protect the faithful from further persecution - a decision further conditioned on abandoning Christian missiology or being subjected to further persecutions: "Thus the persecution of the most dedicated and religiously active believers and pastors never ended under the Soviets. The use of administrative decrees and political articles of the criminal code [in the name of tolerance] were but a thin disguise for religious persecutions against those who saw dissemination of their faith as their primary Christian duty, be they laymen or pastors." ${ }^{\prime 2}$ The lesson to be learned is that Soviet toleration of the ROC was hardly an expression of continuing Christendom, as some today would have it to be.

\section{A New Myth}

Recently, a new understanding of the ROC under Soviet control has emerged, one that seeks not only to rehabilitate the Soviet regime, but also to present Joseph Stalin as an Orthodox saint. As Oleg Yegorov reports, this is a myth now being perpetuated among the laity:

There is a legend saying that it was a miracle that saved Moscow in the winter of 1941, when the Germans were approaching the city: Joseph Stalin supposedly ordered the powers of Orthodoxy to be harnessed to

\footnotetext{
7. See Donald Ostrowski “"Moscow as the Third Rome' as Historical Ghost," in Byzantium: Faith and Power (1261-1557): Perspectives on Late Byzantine Art and Culture, ed. Sarah Brooks (New York: Metropolitan Museum of Art, 2006); Susana Torres Prieto, "Between the Third Rome and the New Jerusalem: The Fall of Constantinople Viewed by the Russians," in New Perspectives on Late Antiquity in the Eastern Roman Empire, ed. Ana de Francisco Heredero, David Hernández de la Fuente, and Susana Torres Prieto (Newcastle: Cambridge University Press, 2014).

8. Dimitry V. Pospielovsky, Soviet Antireligious Campaigns and Persecutions: Volume II of A History of Soviet Atheism in Theory and Practice, and the Believer (London: MacMillan Press, 1988), 1.

9. Pospielovsky, Soviet Antireligious Campaigns, 91.

10. Pospielovsky, Soviet Antireligious Campaigns, 91.

11. Pospielovsky, Soviet Antireligious Campaigns, 1.

12. Pospielovsky, Soviet Antireligious Campaigns, 97.
} 
save his capital. "The miraculous icon of the Theotokos of Tikhvin was flown over Moscow in a plane. So the capital was saved," reported Orthodox journalist Sergei Fomin in his book Russia Before the Second Coming. Like any legend, this one is not true: there is no evidence that Stalin, a Bolshevik atheist, decided to resort to such a strange measure to defeat the enemy. ${ }^{13}$

It is not an isolated account, nor one perpetuated by any one individual alone. The Boris Yeltsin Presidential Library claims Joseph Stalin was secretly a devote Orthodox:

According to the memories of Stalin's bodyguard, Yu Soloviev, who had been with the leader for his last ten years: "In his office there was an icon of Our Lady of Kazan, and he often prayed alone in the inner temple of the Nativity of the Virgin in the Grand Kremlin Palace. ${ }^{14}$

Of course, there is no way to confirm such a sensational claim, and the Russian website provides no proof other than referencing a book that does not seem to exist. ${ }^{15}$ Again, it must be emphasized that these are not isolated occurrences; it is part of a revisionist agenda overseen by leading intellectuals in the Russian political sphere. This was publicized in 2015 when an icon was commissioned by the Izborsk Club, a conservative thinktank led by an ultranationalist Russian political figure Alexander Prokhanov. The icon, entitled "Sovereign Holy Mother," depicts Stalin and his generals on Red Square under the gaze of Mary the mother of Christ. The icon was paraded through a historic battlefield in a commemoration for the fallen soldiers - an event staged by the military and a local priest-monk who offered prayers for the occasion. ${ }^{16}$ It was an event that outraged the Archdiocese for the Belgorod region of the ROC, who did not authorize the event or blessing, nor this outrageous icon depicting a saintly Stalin.

While the local diocese opposed the cynical appropriation of religious imagery, the same cannot be said for the Patriarch Kirill of Moscow and all Russia, the ecclesial head of the ROC. The Russian Orthodox cathedral for the Russian Armed Forces was originally to include religious mosaics commemorating Stalin, as well as current President Vladimir Putin, who was to be depicted celebrating the 2014 annexation of Crimea. ${ }^{17}$ Once this was learned public outcry forced the mosaics to be abandoned, yet the Soviet era flag and communist symbolism still appears throughout the cathedral interior. Again, the issues here are not just a conflation of patriotism and religion, ${ }^{18}$ but a corruption of the very theology for icons and church architecture with themes of blatant militarism in furtherance of a new expansionist agenda. This was showcased at the dedication ceremony, when Patriarch Kirill announced, "with this harmony between the

13. Oleg Yegorov, "Why did Stalin rehabilitate the Russian Orthodox Church?," Russia Beyond, December 4, 2019, https://www.rbth.com/history/331371-stalin-orthodox-church.

14. "The Russian Orthodox Church During the Great Patriotic War," Boris Yeltsin Presidential Library, accessed August 10, 2021, https://www.prlib.ru/en/news/658956.

15. The Boris Yeltsin Presidential Library website claims that, "the fact is described in the book of Paul Pobedonostev." No author by that name (or similar), however, could be found through my research.

16. As documented by Natalya Mihailova in "Russian Orthodox Church Outraged by Appearance of 'Stalin Icon,", Pravmir.com, June 5, 2015, https://www.pravmir.com/russian-orthodox-church-outraged-by-appearance-of-stalin-icon/.

17. See Maria Kiselyova and Gareth Jones, "Russian Inaugurates Cathedral Without Mosaics of Putin, Stalin," Reuters, June 14, 2020, https://www.reuters.com/article/us-russia-military-church-idUSKBN23L0K7.

18. No nation is immune from this natural tendency to take pride in one's heritage and religion, even seeing them as synonymous at times. But in Russia this takes on a particular expression, something immortalized in Fyodor Dostoevsky's great and influential novel, The Demons (1871-1872). In the narrative, the character Ivan Pavlovich Shatov declares: "I believe in Russia. I believe in the Greek Orthodox Church. I-I believe in the Body of Christ-I believe that the second coming will take place in Russia." The point to be taken is that Christ is now seen as a particularly Russian revelation. For further discussion, see Cyril Hovorun, "Civil Religion in the Orthodox Milieu," in Political Theologies in Orthodox Christianity: Common Challenges and Divergent Positions, ed. Kristina Stoeckl, Ingeborg Gabriel, and Aristotle Papanikolaou (New York: Bloomsbury T\&T Clark, 2017). 
might of the armed forces and the spiritual might of the Church, of the spiritual and the material, of the Church and State, let the path of our people go into the future in peace and prosperity, and of this path, God willing, let there be new victories, new achievements, and no defeats." 19 The Minister of Defense of the Russian Federation, Sergey Shoygu, who oversaw the construction of the cathedral, likewise declared that it represents, "the symbol of unity between the heavenly and earthly hosts [that is, armies]." 20 The claimed unity between of the armies of God and those of the Russian Federation forces is exceptionally disturbing. No longer is the ROC simply praying for the wellbeing of the nation and the armed forces, as it is called for in the Divine Liturgy, that God may "grant that they may govern in peace" (The Holy Anaphora). No, this is the inauguration of a new Christendom that sees the military as being divinely sanctioned by God.

And so, as a comparative example, while it is common for naval warships to have a chapel for the faithful crew, ${ }^{21}$ the creation of a cathedral celebrating war itself is something else entirely. Andrei Kuraev, an Orthodox theologian and former Protodeacon, who was defrocked by Patriarch Kirill in December 2020 for his outspoken criticisms of the church, decried the cathedral for what it represents: "I am afraid this is not the subject of a religious Orthodox code, it is a cold object of a new religion, the civil religion of Russia, religion of victory, cult of victory, it turns out that our altar is not dedicated to Christ, to Christ's victory, but is something completely different." ${ }^{22}$ What he is referring to, in part, is the disturbing symbolism of the architecture itself. It has, in fact, been dubbed a "Game of Thrones" cathedral in reference to the popular HBO fantasy series where the king sits atop an iron throne forged from swords of defeated enemies. ${ }^{23}$ So too here war trophies have been incorporated into the very structure of the church, including steel from destroyed Nazi tanks. What is even more disturbing is the large, gilded triptych (a folding three-panel enclosure) that contains an icon of the Savior "Not-Made-By-Hands," which has become an emblem for the Russian military. ${ }^{24}$ The backing frame for the icon was made with wood stocks from Soviet MosinNagant rifles from WW2 (the standard service weapon), as well as with wood recovered from a gun-carriage preserved from the Battle of Poltava (1709), the decisive victory of Peter the Great over the Swedish Empire forces. The triptych is housed at the Cathedral, and travels to warzones to inspire the troops in the various wars being fought by the Russian Federation.

To those outside the Orthodox faith, this may sound eccentric but perhaps not controversial. However, icons are not artwork, nor are they to be created with "found objects" such as war memorabilia. ${ }^{25}$ Innovations of this kind are not allowed since the aim is to faithfully transmit received tradition from the

19. Al Jazeera English, "Russian Church Launches Cathedral Dedicated to Armed Forces," June 14, 2020, YouTube video, 2:20, https://www.youtube.com/watch?v=c_e42p0IMqg\&ab_channel=AlJazeeraEnglish.

20. Zvezda (Телеканал Звезда), “The Main Cathedral of the Russian Armed Forces,” June 30, 2020, YouTube video, 38:26, https://www.youtube.com/watch?v=3JfQWfhNErw.

21. See, for example, the photo essay "The Little Church of Agios Nikolaos on Board a Historical Battleship Protecting Greece," Greek City Times, December 9, 2019, https://greekcitytimes.com/2019/12/09/agios-nikolaos-battleship-greece/. 22. Al Jazeera English, "Russian Church Launches."

23. "Russian MPs Back Harsher Anti-Blasphemy Law," BBC, April 10, 2013, https://www.bbc.com/news/world-europe22090308 .

24. For the legend of this icon, see "Image Not Made by Hands," Orthodox Wiki, accessed August 10, 2021, https://orthodoxwiki.org/Image_Not-made-by-hands.

25. While the adornment of icons may include precious gems and gold items donated by the faithful, this may only be an expression of devotional submission to Christ: "Such gifts demonstrate personal piety but also reinforce the power of Christ to intervene, to perform miracles, or to answer the prayers of the pious [...] Gifts offered to the image [icon] were therefore gifts offered to Christ" (Kirstin Noreen, "Shaping the Sacred: Icons, Processions, and the Presence of the Holy," in Icons and the Liturgy, East and West: History, Theology, and Culture, ed. Nicholas Denysenko [Notre Dame, IN: University of Notre Dame Press, 2017], 81). Devotional gifts of this kind are therefore not theological precedent for incorporating war trophies of conquered enemies stained with blood into these holy objects. 
past, though certain minor changes have happened nonetheless. ${ }^{26}$ This is because icons are nothing less than testimony for the theology of theosis itself: they demonstrate the power of God for transfiguring the world into the kingdom of heaven. And so, in their preparation, the material elements of creation (wood, precious metals from the earth, plant pigments, and animal glues) are transformed by the iconographer to become an instrument of God's grace - and as such, they are to be venerated by the faithful. They are not, technically speaking, works of art. Rather, they are an anticipation of the kingdom of God here on earth. And so, while the ancient Israelites took Egyptian gold for their Tabernacle (Exodus 12:35), the same principle cannot hold true for actual weapons of war being showcased for devotional piety. ${ }^{27}$ What is happening in the ROC is nothing less than the celebration of war itself as a moral good - and what is more, in the apocalyptic imagination of some leading intellectuals in Russia, the armed forces of the Third Rome (Moscow) are now seen as set against pagan "Carthage" (meaning, Washington DC) in a fight for a new world order. ${ }^{28}$ But this, in turn, brings up another important question.

\section{The Russian and Byzantine Warrior Saints}

"In this Sign, Conquer!" These words signaled the birth of Christendom - it was a heavenly vision, a sign from God that awoke in Constantine a new understanding that the Christian faith would be the foundation for his empire. Through it, he would win the throne of Caesar Augustus. Yet he himself would only become Christian late in life, when he knew death was near. Only then did he become catechumen, practice piety, and embrace the true message of the scriptures. This makes him a somewhat problematic figure in church history. He certainly did not live a Christ-like life of meekness on the battlefield. It was only when he approached death can this said to be true. So, what then is being celebrated when Emperor Constantine I is recognized as "equal of the Apostles" in Christian hagiography? This question lies at the heart of the vision now being promoted by the ROC with respect to Russkii mir as a return to Christendom. Is war itself a moral good in Orthodox theology? To find an answer, this essay will now have to explore the contrasting traditions of warrior saints in Russia and Byzantium.

The gold domes of the cathedral for the Russian Federation Armed Forces are inspired by the distinctive war helmet worn by Alexander Nevsky (1221-1263), Prince of Novgorod, who led Russian forces to victory over invading German, Swedish, and Estonian forces. Most notably, Nevsky defeated Te-

26. Certain minor changes have occurred, often leading to controversy. For example, the history of Russian iconography has seen deviations from Byzantine tradition, including the addition of an emblem that denotes the iconographer, the commissioner, and the occasion, often depicted with a cartouche scroll motif within the icon. Another noteworthy change is the addition of a heraldic two-headed eagle motif symbolizing the unity of the church and state, which was originally limited to secular artwork, but made its way into icons for the tsar, nevertheless. "Bringing a panegyric content into the icon, the two-headed eagle, as it were, united in people's consciousness the traditional values of Orthodoxy with belief in the mission of the 'Third Rome' with its ideology of absolutism. The two-headed eagle 'descends' to the level of popular icon painting in the 18th and 19th centuries from official images of the late 17th and early 18th centuries, whose content was linked with the struggle against Islam and for the liberation of Azov" (Oleg Tarasov, Icon and Devotion: Sacred Spaces in Imperial Russia [London: Reaktion Books, 2002], 278). While this may serve, in part, as precedent for some of the iconographic changes reflected in the Cathedral, all innovation of this kind is always, and categorically, theologically inappropriate.

27. Saint Gregory of Nyssa teaches that this episode from Exodus is to be understood as typology for the church employing "the wealth of pagan learning" in crafting Byzantine theology (Life of Moses $§ 115$ ). As such, it cannot be rightfully claimed as precedent for war trophies.

28. Vasilios N. Makrides, "Political Theology in Orthodox Christian Contexts: Specificities and Particularities in Comparison with Western Latin Christianity," in Political Theologies in Orthodox Christianity: Common Challenges and Divergent Positions, ed. Kristina Stoeckl, Ingeborg Gabriel, and Aristotle Papanikolaou (New York: Bloomsbury T\&T Clark, 2017), 49. 
utonic crusaders in the "Battle on the Ice" in which thousands of invaders drowned when he lured them onto a frozen lake, which broke under the weight of their armor. This made Nevsky the perfect symbol for Russian resistance during World War II against a new group of German invaders, who would be likewise defeated by the Russian winter and military cunning. The new cathedral, in fact, is located at the site where Russian forces first turned the tide against the Wehrmacht during the Battle of Moscow, a battlefield now rechristened Patriot Park. Nevsky is recognized as a saint (canonized by the ROC in 1547), and widely seen today in Russia as their greatest historical hero. But is patriotism enough to win this exalted status of Saint?

In Byzantine tradition, heroic deeds in the name of the Orthodox faith were never enough to justify canonization unto sainthood. Case in point is the Byzantine Emperor Heraclius (seventh century), who waged a holy war against the Sasanian Empire, which had captured Jerusalem and claimed holy relics from the Church of the Holy Sepulchre as war trophies, including the holy cross itself. Emperor Heraclius not only recaptured all of the Christian lands, but even recovered the holy cross - and what is more, when returning it to Jerusalem, he humbly dismounted his warhorse, stripped off his regalia, and piously carried the cross barefoot through the city gates. Yet even all this was not enough to justify "sainthood" for the emperor himself. Though the events of his life are duly honored in religious art and in historical remembrance, there is no icon for him, as there is for Nevsky. The reason why is that the association of "war hero and saint" is exceptionally problematic, and thus exceedingly uncommon in Orthodox history. ${ }^{29}$

The Roman Martyrology (1916), first published by order of Pope Gregory XIII (1502-1585), then updated and expanded in 1749 by Pope Benedict XIV (1675-1758), brings together the comprehensive history of saints from the beginning of the church, since before the schism with the Orthodox East, to contemporary times. The declared aim was to contrast the biographies of the secular figures that shaped world history with the true heroes:

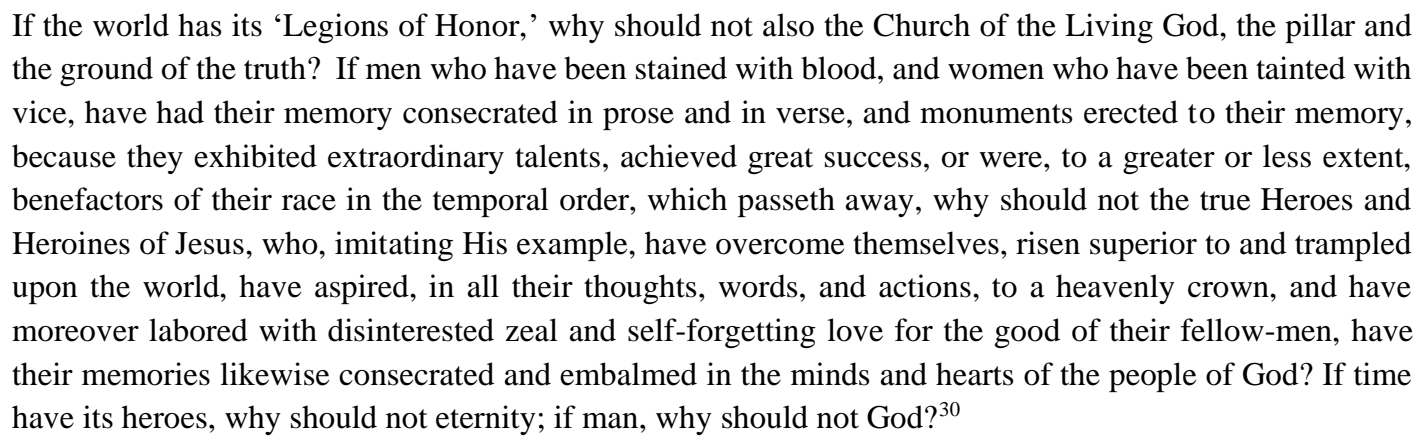

The complied list of saints and their biographies is indeed extensive, numbering in the thousands, and includes people from all walks of life, from clergy to laity, from kings to children, all of whom witnessed the faith in the face of persecution. It even includes military figures. Typically, these are soldiers who were tortured and killed for confessing Christ and refusing to honor pagan Roman emperors by taking up arms on their behalf: they chose martyrdom instead. In the idiomatic phrasing of the martyrology, these warrior

\footnotetext{
29. An additional consideration is that the role of Emperor Heraclius in the Eastern celebration of the Exaltation of the Cross, made clear during the Heraclian dynasty, was later expunged from the liturgy for both political and religious reasons, including for his Monothelite views; curiously, the Western (Catholic) celebrations preserved elements of the Monothelite service until Vatican II. For further discussion, see Anastasia Sirotenko, "Forgetting the Heretic: The Emperor Heraclius in the Byzantine Liturgical Tradition," Jahrbuch der Österreichischen Byzantinistik 67 (2017): 239-248. It is argued here that the problematic association of 'war hero and saint' contributed this denial of sainthood for the emperor by the church.

30. The Roman Martyrology, trans. Archbishop of Baltimore (Baltimore: John Murphy Company, 1916), vi.
} 
saints "threw away their military belts" and became pacifists, even unto death (e.g., St. Victricius, 235f.; Sts. Eudoxius, Zeno, and Macarius, 272f.; et al). This is, of course, in keeping with the biblical paradigm declared in the Gospel of John, that there is no greater love than to lay down one's own life for the sake of another (John 15:12), and exemplified by Christ who was crucified for the sake of the whole world (John $3: 16)$.

Even so, these biblical expectations for nonviolence, however, do stand in stark contrast with those canonized saints who took an altogether different path - that of killing in the name of God. But even then, there are notable differences with the lionized military saints of Russian tradition. Perhaps the best comparative example here is King Kaleb of Ethiopia, the last major Aksumite king of Ethiopia, ruling circa 514-543 CE. Also known as Saint Elesbaan (alternately Ella Atsbeha or Ella Asbeha in Ethiopia, and Hellesthaeeus or Ellesbas in Greek sources), Kaleb saw his kingdom reach is greatest highest of glory in the Byzantine era, is celebrated today as a canonized saint throughout the world, and most especially in Ethiopia where he is honored every year on May 28 (Ginbot 20 per the Ethiopian liturgical calendar). Kaleb was his baptismal name, in honor of the Biblical figure Caleb, who was one of the twelve scouts sent by Moses into Canaan to see if it was indeed the Promised Land (Numbers 13), and later inheriting the area of Hebron within its borders (Joshua 14). Here it should be recalled, that in Christian contexts, the promised land is seen as the biblical type to the prophetic kingdom of heaven to be inaugurated here on earth. King Kaleb, with this very auspicious baptismal name, is therefore to be seen by the faithful as someone who established an outpost in Ethiopia of the kingdom of heaven itself.

King Kaleb's reign extended throughout the Horn of Africa, and even across the Red Sea into modern-day Yemen. Yet tragedy struck, and the Yemenite region fell to Dhū Nuwās (alternately, Yūsuf As'ar Yath'ar) circa $517 \mathrm{CE}$, who mascaraed Christians and burned their churches, forcing those who survived to apostatize from their faith. Refugees fled to the court of Justinian I of Constantinople (482-565 $\mathrm{CE})$, the Byzantine Emperor, who then commanded King Kaleb to retake the conquered lands and liberate the Christian inhabitants. King Kaleb dutifully responded by launching a military campaign to recapture the Yemenite capital Nagran, but was unsuccessful. According to OCA Synaxarion, the king turned to a religious hermit for counsel. The hermit revealed God had opposed the king because his heart was set only on revenge against Dhū Nuwās. He counseled the king to make a vow devoting his final days of life to God, and only then would be victorious.

Kaleb obediently made the vow, regathered his forces, and launched another invasion across the Red Sea. This time he was successful, conquering the capital and freeing the Christian inhabitants. He then went further and gave in to his desire for revenge - and this is where the ethical problems arise. King Kaleb slaughtered all of followers of Dhū Nuwās without exception, the usurper himself only escaped execution through suicide. But that is not why King Kaleb is recognized as a saint. It is what he did afterwards. Remembering his vow, and struck with an unbearable need to repent, the king gave up his throne, all his wealth, and became a landless monastic:

\footnotetext{
His royal crown and his royal apparel, which were of great price, he sent to Jerusalem. And he wrote a letter to Abba John, Archbishop of Jerusalem, asking him to hang up the crown above the doors of the Tomb of our Lord Jesus Christ. And after [this] he went into that rock [that is, a cave in which to live out his days in prayer and repentance] and never spoke to anyone; and he pleased God and died in peace. ${ }^{31}$
}

31. Ethiopian Synaxarion, trans. E. A. Wallis Budge (Garland, TX: Ethiopian Orthodox Tewahedo Debre Meheret St. Michael Church, undated), 525. 
Kaleb thereby abdicated his throne, dedicating his crown to the Church of Holy Sepulchre. He then entered the monastery of Abba Pantaleon, where he spent the rest of his life in a cave with strict fasting and asceticism. This is why he was canonized by the Ethiopian church and became the first Ethiopian to be recognized by the Greek and Roman Catholic churches as a saint - not for armed conquest in the name of Christendom, but for his sincere contrition, humility, and in devoting his life to winning the true crown of Christ (2 Timothy 4:8). So too with Emperor Constantine I. It was not his militarism in creating Christendom, but the humility at the end that is honored. As for the other military saints of Byzantine history, they were martyrs who died while protecting others in defensive military actions (see Skedros 2017). But the ROC seems to have taken another direction in veneration of saints where it seems that patriotism alone qualifies one for sainthood. ${ }^{32}$

While I discuss the subject of just war in the Orthodox tradition at length elsewhere, ${ }^{33}$ it should be observed here that His All Holiness, the Ecumenical Patriarch of Constantinople Bartholomew I cautions that only "in a few specific cases the Orthodox Church forgives an armed defense against oppression and violence." ${ }^{34} \mathrm{He}$ instead counsels that it is better "to be treated with injustice ourselves than to do injustice to others." ${ }^{35}$ This is because, as he asserts, "war and violence are never means used by God in order to achieve a [just] result." ${ }^{36}$ At risk of serious understatement, it is very evident that the ROC now stands apart from Constantinople in many tragic ways, not least of which is the new attitude towards war in the name of its Third Rome claims.

\section{Theology of the Cross}

In this conflict between the ROC and Constantinople, it is useful to bring in another perspective on Christendom, that of Douglas John Hall. Writing from a protestant perspective (drawn from work of reformer Martin Luther), Hall looks back on the history of Christendom without the sense of loss and tragedy that many Orthodox and Catholics still feel. From this place of comparative impartiality, Hall concludes that, "the truth is, surely, that Christianity was never designed for the imperial cultus that it became and that serve that end be becoming [...] something else altogether [..] an aberration, a mutation. ${ }^{37}$ The erasure of Christian empire from the political, and especially the military spheres of public life, is becoming more and more a reality in the west, and it is by no means a tragedy. Rather, Hall writes: "The Christian faith is being made free from its Babylonian captivity to political, cultural, racial, and (yes) religious structures that it may and become what in essence it is: salt, yeast, light - a vigilant and prophetic diaspora in the midst of a global society that will from now on manifest immense multiplicity and the intermingling of people, cultures, and cults. Christians ought to embrace this possibility." 38 He warns that, "to seek to impede the process of disestablishment or to reverse it, and to attempt in the face of all odds to win the whole world for the Christian religion is not only foolish; it is disobedient!" 39 The true mission of the church is to witness the faith as it once was, in opposition to empire, the time when Christians died for

32. Other Russian warrior saints include Admiral Fedor Ushakov (1745-1817), an undefeated naval commander on the Black Sea, and Ilya Muromets (beatified in 1643), a legendary Bogatyr knight of remarkable size and strength.

33. David K. Goodin, Confronting Evil: Theodicy in the Eastern Patristic Tradition (Montreal: Alexander Press, 2021).

34. Bartholomew I, "War and Suffering," in Cosmic Grace - Humble Prayer: The Ecological Vision of the Green Patriarch

Bartholomew I, ed. John Chryssavgis (Grand Rapids, Michigan: William B. Eerdmans, 2003), 262. My emphasis.

35. Bartholomew I, "War and Suffering," 263.

36. Bartholomew I, "War and Suffering," 262. My emphasis.

37. John Douglas Hall, The Cross in Our Context: Jesus and the Suffering World (Minneapolis: Fortress Press, 2003$), 168$.

38. Hall, The Cross, 169.

39. Hall, The Cross, 168. 
the sake of their neighbors through pacificist martyrdom - like St. Ignatius of Antioch (reposed c.107), like St Polycarp of Smyrna (reposed 155). It is not the warriors who created an empire and called it Christian; it is these saints who heralded the true kingdom of God that should be celebrated.

For us today, we are likewise called to be martyrs as they were, but this time martyrs of conscience (to borrow the Orthodox phrase) ${ }^{40}$ in pursuing social justice for the poor, the disenfranchised, the marginalized, and the forgotten in the name of Christ - which Hall reminds us is the true meaning of discipleship $^{41}$ (Mark 8:34). Only through disestablishment from the state apparatuses of power will the church be able to fulfil its mission to the "lost sheep" of society. The secularization of society is not to be feared or resisted for, as Hall reminds us, "Christianity is being liberated from the burden of folk religion [that is, popular biases and political agendas], of legitimizing secular powers, of being the moral police of our society." ${ }^{\prime 2}$ When this happens, the church once again gains the clarity of purpose it once enjoyed during the pre-Constantine age of martyrs. We are to change the world only through moral persuasion, and one saved sinner at a time. The true church must embrace this path and defend the powerless from the oppressive powers of the State. The ROC, however, has chosen another path.

Metropolitan Hilarion of Volokolamsk, chairman of the Moscow Patriarchate's Department for External Church Relations and Board Member for the Russkiy Mir Foundation, gave the keynote address for the Christian Future of Europe Conference, an international symposium, on September 22, 2017. His address is remarkable for several reasons, the foremost of which is that he declares that Christianity is dying out in the West, only truly being alive in the ROC. He further warns of certain social and political issues will become worse if this trend continues:

\begin{abstract}
The other reason for the transformation of the religious map of Europe is the secularization of European society. [...] We can see an opposite trend in the Eastern European countries, in particular in Russia. [...] The modern-day decline of Christianity in the western world may be compared to the situation in the Russian Empire before 1917. The revolution and the dramatic events which followed it have deep spiritual, as well as social and political, reasons. Over many years the aristocracy and intelligentsia had abandoned the faith, and were then followed by common people. [...] I firmly believe that a Europe which has renounced Christ will not be able to preserve its cultural and spiritual identity. [...] The architects of the secular society have seen to the legal aspect of the issue: formally one can confess any religion, but if one attempts to motivate one's actions through religious belief and freedom of conscience and encourage others to act in accordance with their faith, then at best one will be subjected to censure, or at worst to criminal prosecution. For example, if one is a doctor and refuses to perform an abortion, or euthanasia, by referring to one's religious principles, then one is breaking the law. If you are a Protestant pastor and live in a country in which same sex unions are legal, then you have little chance of refusing this couple the right to a church wedding while remaining unpunished by the state. [...] In modern-day Europe militant secularism has been transformed into an autonomous power that does not tolerate dissent. It allows well-organized minority groups to successfully impose their will on the majority under the pretext of observing human rights. Today human rights have in essence been transformed into an instrument for manipulating the majority, and the struggle for human rights into the dictatorship of the minority in relation to the majority. ${ }^{43}$
\end{abstract}

40. Peter of Damaskos, The Philokalia, vol. 3, ed. and trans. G. E. H. Palmer, Philip Sherrard, and Kallistos Ware (London: Faber \& Faber, 1986), 161.

41. Hall, The Cross, 184.

42. Hall, The Cross, 169.

43. Metropolitan Hilarion of Volokolamsk, "Keynote Address," presented at the Christian Future of Europe Conference, Russian Embassy in London, UK, September 22, 2017, https://mospat.ru/en/news/48190/. 
The speech reveals how the ROC sees its own relationship to the state ${ }^{44}$ that legal powers are to be wielded to enforce the church's moral teachings and to punish disobedient citizens. This is perhaps most exceptionally revealed in an issue Hall writes about extensively, the persecution of homosexuality in the name of Christian values. His views stand in sharp contrast with how the ROC seeks the criminalization of LGBTQ+ persons.

Many will recall how the ROC punished the "punk prayer" of the avant-garde band Pussy Riot, which was performed before the iconostasis of Moscow's Christ the Savior Cathedral, during which the band prayed to the Theotokos to protect gay citizens from being persecuted by Putin, and to condemn the blatant corruption of ROC hierarchs. ${ }^{45}$ It was by no means blasphemous or sacrilegious, especially considered in light of the long tradition of "Fools for Christ" (1 Corinthians 4:10) in Russian tradition - that is, those who take on the aspect of madness or ridiculousness in order to speak truth to power. In response, the ROC pressed criminal charges of blasphemy against two band members, Maria Alyokhina and Nadezhda Tolokonnikova, who were sentenced to two-year prison terms. The ROC then lobbied for even more stringent criminal and civil penalties for such acts of defiance, which the state was happy to oblige. ${ }^{46}$ It represents, not only an abandonment of any pretense of separation between church and state, but also of the very mission of the church to minister to those most in need as commanded by Christ (Matthew 25). This includes those who are being persecuted by state authorities, just as Christ was by Pontius Pilate. Disturbingly, the ROC has been conspicuously muted in its criticism of the state-sponsored murder and torture of LGBTQ+ persons in Chechnya. ${ }^{47}$ Not only that, but they have further pushed through legislation that decriminalizes domestic violence throughout Russia in the name of family values. ${ }^{48}$

\section{The Two Swords of Orthodoxy}

The ROC has taken an unprecedented path away from Orthodox tradition, for at the height of Byzantium, the true role of the church was to oppose the emperor in the name of social justice. The foremost theologian of all Orthodoxy is, arguably, St. John Chrysostom (347-407). He declared, concerning the place of the church in relation to the civil authority, that "neither has authority of this kind for the restraint of sinners been given us by law, nor, if it had been given, should we have any field for the exercise of our power, inasmuch as God rewards those who abstain from evil by their own choice, not of necessity." 49 This

44. For further discussion of the larger geopolitical and domestic issues here, see: Nicholas Denysenko, "Fractured Orthodoxy in Ukraine and Politics: The Impact of Patriarch Kyrill's 'Russian World," Logos: A Journal of Eastern Christian Studies 54, no. 1-2 (2013): 33-68; Kristina Stoeckl, The Russian Orthodox Church and Human Rights. (London: Routledge, 2014); Anton Shekhovtsov, Russia and the Western Far Right: Tango Noir (New York: Routledge, 2018); Moritz Pieper, "Russkiy Mir: The Geopolitics of Russian Compatriots Abroad" Geopolitics 25, no. 3 (2018): 756-779.

45. Jeffery Tayler, "What Pussy Riot's 'Punk Prayer' Really Said," November 8, 2012, The Atlantic, https://www.theatlantic.com/international/archive/2012/11/what-pussy-riots-punk-prayer-really-said/264562/

46. "Russian MPs back harsher anti-blasphemy law," April 10, 2013, BBC, https://www.bbc.com/news/world-europe22090308 .

47. Kate Connolly, "Merkel Presses Putin Over Anti-Gay Purge in Chechnya," The Guardian, May 2, 2017, https://www.theguardian.com/world/2017/may/02/angela-merkel-vladimir-putin-russia-investigate-lgbt-torture-claims-

chechnya. See also the reporting of Caroline Schmitt for Deutsche Welle: "responding to allegations that the ROC turns gay citizens into targets of police violence, [Vakhtang] Kipshidze [a representative of the ROC] refused to criticize the police directly, only saying: "We are against violence. We are against violence which is directed to any social groups." See: "Is the Russian Orthodox Church Serving God or Putin?,” Deutsche Welle, April 26, 2017, https://www.dw.com/en/is-therussian-orthodox-church-serving-god-or-putin/a-38603157.

48. "Serving God or Putin?"

49. John Chrysostom, On the Priesthood, 2.3. For all references to Chrysostom, see: "Chrysostom: On the Priesthood, Ascetic Treatises, Select Homilies and Letters, Homilies on The Statues," in Nicene and Post-Nicene Fathers, vol. 9, ed. 
is a clear line of demarcation between the church and state. Since free will is foundational for the salvation of the congregation, those who perform crimes must be handled by a secular authority:

For Christians above all men are not permitted forcibly to correct the failings of those who sin. Secular judges indeed, when they have captured malefactors under the law, show their authority to be great, and prevent them even against their will from following their own devices: but in our case the wrong-doer must be made better, not by force, but by persuasion. ${ }^{50}$

Rather, speaking for the role of the church, Chrysostom declared that the only power for the priesthood is persuasion with respect to moral failings within society:

We have 'not lordship over your faith' [2 Corinthians 1:24], beloved, nor command we these things as your lords and masters. We are appointed for the teaching of the word, not for power, nor for absolute authority. We hold the place of counselors to advise you. The counselor speaks his own sentiments, not forcing the hearer, but leaving him full master of his choice upon what is said. ${ }^{51}$

Chrysostom saw the role of the church as being called to correct the imperfections of the secular authorities through critical engagement. Chrysostom even went as far as to issue thinly veiled warnings to the emperor from the pulpit:

For of governments there are some natural, and others which are elective; - natural as of the lion over the quadrupeds, or as that of the eagle over the birds; elective, as that of an Emperor over us; for he doth not reign over his fellow-servants by any natural authority. Therefore it is that he oftentimes loses his sovereignty. ${ }^{52}$

The brazen and fearless criticism also extended to personal attacks. He even publicly criticized the Empress Eudoxia, comparing her at one point to the biblical figure of Jezebel for having seized private property in the name of the State. ${ }^{53}$ While this public conflict between the Empress and Chrysostom has often been cited as cause for his downfall, it was equally true that his challenges to the social elite on behalf of the poor, and specifically his insistence on building a lepertorium outside Constantinople, which lead to his disposition and death. What is especially pertinent here to this discussion is that Chrysostom saw for the church an opportunity to embrace martyrdom for the sake of social justice. To put it simply, Christianity should never see itself synonymous with nationalistic identity or political agendas, lest it falls victim to the diabolic temptation of pride (Matthew 4:9). Our true mission is to be found in Matthew 25.

Alexander Roberts and James Donaldson, and A. Cleveland Coxe (Grand Rapids: WM. B. Eerdmans Publishing Company, 1996).

50. Chrysostom, On the Priesthood, 2.3.

51. Chrysostom, Homilies on Ephesians 11:15, 16. My emphasis. Chrysostom's admonitions notably contrast with Augustine of the Catholic west, who wrote: "For originally my opinion was, that no one should be coerced into the unity of Christ, that we must act only by words, fight only by arguments, and prevail by force of reason" (Augustine, Letter 93, 5.17, in Nicene and Post-Nicene Fathers, vol. 1, trans. J. G. Cunningham, ed. Philip Schaff [Buffalo, NY: Christian Literature Publishing Co., 1887], http://www.newadvent.org/fathers /1102093.htm). But then Augustine embraced the use of legal authority to forcibly impose the church's will over society, observing how effective it was to defeat all perceived heretics and for them to be "brought over to the Catholic unity by fear of the imperial edicts" (Augustine, Letter 93, 5.17). This legal compulsion took the form of civil fines, criminal punishment, exile, and other forms of persecution.

52. Chrysostom, Homilies on the Statues to the People of Antioch 7.3.

53. John Hugo Wolfgang Gideon Liebeschuetz, Barbarians and Bishops: Army, Church, and State in the Age of Arcadius and Chrysostom (Oxford: Oxford University Press, 1990), 199. 


\section{Closing Statements}

St. Paul was personally scolded by God that, "My grace is sufficient for you, for My strength is made perfect in weakness" (2 Corinthians 12:9). It was an admonition important for Paul's own piety, but it is also something that holds true for us today in coming to terms with a post-Christendom world. It is especially relevant for those who desire to resurrect a dead vision of Christian empire to rule over society. When the piety of weakness is cast aside in order to grasp the reigns of secular power for political agendas, no longer are we the light of the world (Matthew 5:14-16). Only evil triumphs when we refuse God's call to discipleship, ignoring the promptings of conscience for social justice. Truly, patriotism is not wrong, and neither is military service given in defense of a nation. Yet both can become corrupted when it is imagined that God's apocalyptic plans are furthered by military conquests in the name of Christ. Nazi Germany felt this way, boldly emblazing their military uniforms, Gott Mit Uns. Yet they were proven wrong by the unforgiving Russian winter and the spirited defense of the Russian homeland when atheists and Orthodox fought side by side. Yet today in Russia, church and state are heralding a vision of Russkii mir that seeks to erase all secularism, liberalism, and progressive elements from their lands. Long lost is the lesson of true Byzantium, where the church wielded the power of persuasion and nothing more, for the church knew that people must be free to choose the direction of their moral lives, for free will is God's will for us. ${ }^{54}$ Yet even now, nothing prevents the true Christian mission of ministering to the power and disenfranchised, especially those being crushed by tyrannical powers of the State. The ROC has a clear choice to make, whether to take for itself the kingdoms of the world through political allegiance and violence, or to surrender political power after the example of King Kaleb, living only for Christ instead. It remains to be seen if they will pick up their Crosses and follow Him who gave His life for the life of the world (Matthew 16:24, John 3:16). ${ }^{55}$

54. For further discussion, see Goodin, Confronting Evil.

55. I am reminded here of the words of Metropolitan Tikhon, Archbishop of Washington and Metropolitan of All America and Canada for the Orthodox Church in America (OCA). The OCA gained its autocephaly from the ROC in 1970. The Most Blessed Tikhon, in Of What Life Do We Speak? (2018), responds to the challenge set forth by Alexander Schmemann in his book, For the Life of the World (1963) regarding authentic Christian mission. Father Schmemann was concerned about the effects of secularism on Christian self-understanding, by which he meant that our experience of God has been increasingly confined to certain "sacred spaces" of our lives, like Sunday liturgy, but has otherwise abandoned the rest of the world to another realm, a profane one. Gone, he writes, is any sense of Christian mission to the world. Tikhon, like Schmemann before him, calls for Christian renewal through embracing prophetic witness: "But neither a desperate effort to artificially force the Church to be relevant, nor an anxious clinging to a fossilized understanding of tradition will help us in the realities in which we live. The importance of Father Alexander's work, For the Life of the World, lies precisely in that it traces the middle way between these approaches and, more importantly, offers a prophetic witness in the present, that is, to the heart of man. Because Christ is the foundation of all things, we cannot be swayed by whatever philosophical, political, or ideological winds may blow one direction or another. Only through a deep abiding with Christ in our hearts through prayer, obedience, humility, and love, can we hope to stand on the solid rock of faith and to thereby make a small contribution to the questions and problems of the world" (Tikhon, Of What Life Do We Speak? [Washington, DC: The Orthodox Church in America, 2018], 56). 


\section{Bibliography}

Bartholomew I. "War and Suffering." In Cosmic Grace - Humble Prayer: The Ecological Vision of the Green Patriarch Bartholomew I, edited by John Chryssavgis, 261-264. Grand Rapids, MI: William B. Eerdmans Publishing Company, 2003.

BBC. "Russian MPs back harsher anti-blasphemy law." April 10, 2013. https://www.bbc.com/news /worldeurope-22090308

Boris Yeltsin Presidential Library. "The Russian Orthodox Church during the Great Patriotic War." April 10, 2015. https://www.prlib.ru/en/news/658956.

Connolly, Kate. "Merkel Presses Putin Over Anti-Gay Purge in Chechnya. The Guardian, May 2, 2017. https://www.theguardian.com/world/2017/may/02/angela-merkel-vladimir-putin-russia-investigatelgbt-torture-claims-chechnya.

Denysenko, Nicholas. "Fractured Orthodoxy in Ukraine and Politics: The Impact of Patriarch Kyrill's 'Russian World.'” Logos: A Journal of Eastern Christian Studies 54, no. 1-2 (2013): 33-68.

Dmytryshyn, Basil. Medieval Russia: A Source Book, 850-1700. Fort Worth, TX: Harcourt Brace Jovanovich, 1991.

Ethiopian Synaxarion. Translation by E. A. Wallis Budge. Garland, TX: Ethiopian Orthodox Tewahedo Debre Meheret St. Michael Church, undated.

Gallego, Sonia. "Russian Church Launches Cathedral Dedicated to Armed Forces." Al Jazeera, June 14, 2020. https://www.youtube.com/watch?v=c_e42p0IMqg\&ab_channel=AlJazeeraEnglish.

Goodin, David K. Confronting Evil: Theodicy in the Eastern Patristic Tradition. Montreal: Alexander Press, 2021.

Gavrilyuk, Paul L. "The President and the Patriarch: An Alliance over Ukraine?" First Things, April 1, 2014. https://www.firstthings.com/web-exclusives/2014/04/the-president-and-the-patriarch.

Greek City Times. "The Little Church of Agios Nikolaos on Board a Historical Battleship Protecting Greece.” December 9, 2019. https://greekcitytimes.com/2019/12/09/agios-nikolaos-battleshipgreecel.

Gregory of Nyssa. The Life of Moses. Translated by Abraham J. Malherbe and Everett Ferguson. New York: Paulist Press, 1978.

Hall, Douglas John. The Cross in Our Context: Jesus and the Suffering World. Minneapolis: Fortress Press, 2003. 
Hilarion of Volokolamsk. "Keynote Address." Presented at the Christian Future of Europe Conference, Russian Embassy in London, UK, September 22, 2017. https://mospat.ru/en/news/48190/.

Hovorun, Cyril. "Civil Religion in the Orthodox Milieu." In Political Theologies in Orthodox Christianity: Common Challenges and Divergent Positions, edited by Kristina Stoeckl, Ingeborg Gabriel, and Aristotle Papanikolaou, 253-264. New York: Bloomsbury T\&T Clark, 2017.

Kiselyova, Maria, and Gareth Jones. "Russian Inaugurates Cathedral Without Mosaics of Putin, Stalin." Reuters, June 14, 2020. https://www.reuters.com/article/us-russia-military-church-idUSKBN23 L0K7.

Kuzio. Taras. "Putin Forever: Ukraine Faces the Prospect of Endless Imperial Aggression." Atlantic Council, February 13, 2020. https://www.atlanticcouncil.org/blogs/ukrainealert/putin-foreverukraine-faces-the-prospect-of-endless-imperial-aggression/.

Liebeschuetz, J. H. W. G. Barbarians and Bishops: Army, Church, and State in the Age of Arcadius and Chrysostom. Oxford: Oxford University Press, 1990.

Makarios, and Nikodimos, comps. The Philokalia. Vol. 3. Edited and translated by G. E. H. Palmer, Philip Sherrard, and Kallistos Ware. London: Faber \& Faber, 1986.

Makrides, Vasilios N. "Political Theology in Orthodox Christian Contexts: Specificities and Particularities in Comparison with Western Latin Christianity." In Political Theologies in Orthodox Christianity: Common Challenges and Divergent Positions, edited by Kristina Stoeckl, Ingeborg Gabriel, and Aristotle Papanikolaou, 25-54. New York: Bloomsbury T\&T Clark, 2017.

Mihailova, Natalya. "Russian Orthodox Church Outraged by Appearance of 'Stalin Icon."” Pramir.com June 5, 2015. https://www.pravmir.com/russian-orthodox-church-outraged-by-appearance-of-stalinicon/.

Noreen, Kirstin. "Shaping the Sacred: Icons, Processions, and the Presence of the Holy." In Icons and the Liturgy, East and West: History, Theology, and Culture, edited by Nicholas Denysenko, 77-103. Indiana: University of Notre Dame Press, 2017.

Ostrowski, Donald. 2006. "'Moscow as the Third Rome' as Historical Ghost." In Byzantium: Faith and Power (1261-1557): Perspectives on Late Byzantine Art and Culture, edited by Sarah Brooks, 170179. New York: Metropolitan Museum of Art.

Pieper, Moritz. "Russkiy Mir: The Geopolitics of Russian Compatriots Abroad." Geopolitics 23, no. 3 (2018): 1-24. https://doi.org/10.1080/14650045.2018.1465047

Pifer, Steven. "Crimea: Six Years After Illegal Annexation.” Brookings Institute, March 17, 2020. https://www.brookings.edu/blog/order-from-chaos/2020/03/17/crimea-six-years-after-illegalannexation/. 
Pospielovsky, Dimitry V. Soviet Antireligious Campaigns and Persecutions: Volume II of A History of Soviet Atheism in Theory and Practice, and the Believer. London: MacMillan Press, 1988.

Prieto, Susana Torres. "Between the Third Rome and the New Jerusalem: The Fall of Constantinople Viewed by the Russians." In New Perspectives on Late Antiquity in the Eastern Roman Empire, edited by Ana de Francisco Heredero, David Hernández de la Fuente, and Susana Torres Prieto, 258277. Newcastle: Cambridge University Press, 2014.

Roberts, Alexander and James Donaldson, eds. Nicene and Post-Nicene Fathers. 1st series, vol. 9. Grand Rapids, MI: William B. Eerdmans Publishing Company, 1996.

Gregory XII. Roman Martyrology. Updated and expanded by Pope Benedict XIV. Translated by the Archbishop of Baltimore. Baltimore, MD: John Murphy Company, 1916.

Runciman, Steven. The Great Church in Captivity. Cambridge: Cambridge University Press, 1968.

Schaff, Philip, ed. Nicene and Post-Nicene Fathers. 1st series, vol. 1. Translated by J. G. Cunningham. Buffalo, NY: Christian Literature Publishing Co., 1887. http://www.newadvent.org/fathers /1102093.htm.

Schmemann, Alexander. For the Life of the World: Sacraments and Orthodoxy. Crestwood, NY: Saint Vladimir's Seminary Press, 2002.

Schmitt, Caroline. "Is the Russian Orthodox Church Serving God or Putin?" Deutsche Welle, April 26, 2017. https://www.dw.com/en/is-the-russian-orthodox-church-serving-god-or-putin/a-38603157.

Shekhovtsov, Anton. Russia and the Western Far Right: Tango Noir. New York: Routledge, 2018.

Sirotenko, Anastasia. "Forgetting the Heretic: The Emperor Heraclius in the Byzantine Liturgical Tradition.” Jahrbuch der Österreichischen Byzantinistik 67 (2017): 239-248.

Skedros, James. "Lessons from Military Saints in the Byzantine Tradition." In Orthodox Christian Perspectives on War, edited by Perry Hamalis and Valerie Karras, 195-214. Notre Dame, IND: University of Notre Dame Press, 2017.

Stoeckl, Kristina. The Russian Orthodox Church and Human Rights. London: Routledge, 2014.

Tarasov, Oleg. Icon and Devotion: Sacred Spaces in Imperial Russia. London: Reaktion Books, 2002.

Tayler, Jeffery. "What Pussy Riot's 'Punk Prayer' Really Said." The Atlantic, November 8, 2012. https://www.theatlantic.com/international/archive/2012/11/what-pussy-riots-punk-prayer-reallysaid/264562/. 
Tikhon, Archbishop of Washington and Metropolitan of All America and Canada. Of What Life Do We Speak? Four Pillars for the Fulfillment of the Apostolic Work of the Church. Syosset, NY: The Orthodox Church in America, 2018.

Yegorov, Oleg. "Why did Stalin rehabilitate the Russian Orthodox Church?” Russia Beyond, December 4, 2019. https://www.rbth.com/history/331371-stalin-orthodox-church.

Zvezda (Телеканал Звезда). “The Main Cathedral of the Russian Armed Forces.” June 30, 2020. YouTube video, 38:26. https://www.youtube.com/watch?v=3JfQWfhNErw. 